the University of Virginia, 1955. $217 \mathrm{p}$. $\$ 20.00$ ( $\$ 10.00$ to members.)

To his constantly useful Index to the Pollard-Redgrave Short-Title Catalogue, printed in 1950 by photo-offset, Dr. Morrison has now added a similar Index to the 80,000 entries in Wing. One could wish to revive a useful old word to praise such "indicular" devotion: countless hours of patient listing have produced a tool that younger scholars will soon be taking for granted. But the tool here provided will assuredly continue for a few years to seem to older workers almost miraculous in the ease with which it now makes possible any search for books of a known printer or bookseller: in the dull columns now laid before us is a quick identification of any English book that contains the name Abington or Young in its imprint, or any name in between, and then one can continue to study the publishing history of that man. Even the arrangement by years under each name has a distinct convenience.

One immediate value of this Index will be its capability of correcting or supplementing the information in the Term Catalogues and Plomer's lists as to the span of years during which the different booksellers remained active; in fact, this will make the needed revision of Plomer almost easy. Every book here recorded under a man's name may possibly add to the sum of knowledge concerning his activity. (Some caution will be required because Dr. Morrison has purposely combined two or more men of the same name into one list, e.g., Barker and Daniel.)

No doubt some errors have crept in during the indexing, transcribing, setting in type, and proofing of such a staggering mass of numbers. But the work seems steadily accurate, and any errors can be readily corrected in use. A few false dates have been left uncorrected, for example, whether or not Wing corrected them, to produce slightly startling entries with dates earlier than I64I, as under John Bill, John Crouch, Leonard Lichfield, William Marshal, and Henry Twyford. Somewhat oddly, Dr. Morrison apologizes in his preface for two strange entries in the Index, each of which could have been verified or corrected, to judge by the locations in Wing, by a single inquiry addressed to an American librarian.-A. T. Hazen, Columbia University.

\section{Recent Foreign Books on the Graphic Arts, Bibliography, and Library Science}

Shortly before World War I, O. Willmann and E. M. Rohloff edited an important Lexikon der Pädagogik in five volumes. In 1930-32 this work was supplemented and brought up-to-date by the Lexikon der Pädagogik der Gegenwart, edited by the Deutsches Institut für Wissenschaftliche Pädagogik in Münster, Westphalia. Important as these seven volumes were, it was out of the question to attempt to issue further supplementary volumes. Only a completely new edition could be satisfactory and this is what the Deutsches Institut in Münster and the Institut für Vergleichende Erziehungswissenschaft in Salzburg have given us in the new Lexikon der Pädagogik (Freiburg: Herder, 1952-55; 4 vols.; DM 224. for the set).

In the very beginning one important point should be emphasized about this great reference work: although the publisher is a leading Catholic firm, and although the sponsorship and orientation of the work is basically Catholic, the breadth and bona fide objectivity of the Lexikon lend it a significance that reaches far beyond any sectarian limitation. In many respects the Catholic orientation is positively a virtue, for example, in the adequate treatment of the history of education in the Middle Ages. Moreover, in the absence of any Protestant or non-sectarian encyclopedia of education, the Lexikon must be recognized as the one definitive recent work of its type.

The complete work contains contributions by over 700 authorities. There are 3,950 articles and references. The exhaustive index at the end of the fourth volume contains some 16,500 entries. Every aspect of the history, practice, and theory of education is represented for the new Lexikon proposes to be absolutely comprehensive in its field.

Each article is signed by the name of the author. Contributors are identified in a list at the beginning of each volume. This list is followed by an alphabetical list of articles with page numbers to serve as a sort of table of contents. Comparatively few abbreviations (for a work of this magnitude) are used, but 
they are consistent and may be quickly identified in a table at the front of each volume. There is a selected bibliography at the end of each article, and the fact that many references bear a date only shortly before press time is indicative of the alertness of the editors. In the case of biographical articles there are lists of the subject's main works as well as of articles and books about him. Bibliographical references are given in all languages, but there is a natural predominance of German. Unfortunately there are some references to articles in relatively obscure periodicals not generally available in this country, but that is no fault of the editors.

Perhaps one of the most striking aspects of the Lexikon is its breadth and truly international character. It represents the one tradition in German education, the Catholic one, that the Nazis were never able to exile or destroy. It is a tradition that is just as strong today in the relatively few centers of Catholicism in East Germany, where the regime is an even more implacable foe of religion than National Socialism was. Thus, in the Lexi$k o n$ we find impressively accurate evaluations of moral rearmament, R. M. Hutchins, or the idea of "fair play" (entered under the English words). The Lexikon is bringing to Germany ideas that were excluded for a decade and a half, but in doing so it is organizing the whole corpus of modern pedagogical knowledge so that it will be in a useful reference form for educators everywhere.

The Lexikon has the happy virtue of combining the ready reference function with the encyclopedic. Articles and cross references are organized so that essential information is available at a glance, but there are also many detailed surveys of certain key subjects. Nearly all articles are well written, and few are burdened with the oppressively erudite style of most specialized German encyclopedias.

For the librarian, either in a popular or reference collection, the potential value of the Lexikon is high. The relationship of philosophy, psychology, sociology, and even theology to education are much the same as to librarianship. To take but a couple of examples of articles of greatest value to librarians, references may be made to those on the history of universities and to those on adult education.

The new Lexikon der Pädagogik is a reference work of prime importance. Both the four volumes of the set and a volume entitled Pädagogik im Bilde, a sort of a pictorial supplement announced for early publication by Herder, will have a basic place in any reference collection in college and university libraries and in many public libraries as well.

A new title in Martinus Nijhoff's distinguished list of bibliographical titles in the Bibliotheca catholica neerlandica impressa, I500-I727 (The Hague: Nijhoff, I954; 669 pages; fl. 40). It is a short-title catalogue of I8,754 titles printed in the Low Countries (Netherlands and Belgium) from 1500 to 1727. All books relating to any aspect of Catholicism that appeared in the Low Countries during this period were included insofar as they were identified. Although most of the titles are in Dutch or Latin, the basic criterion for inclusion was the place of printing rather than the language. The arrangement is chronological, but there is an alphabetical author and title index.

The bibliography was compiled by several hands and from various sources, including books and periodicals, catalogs of libraries and antiquarian book dealers, biographies as well as bibliography. A source is given for every title in the bibliography. No effort was made to consult the texts. Neither was every source used compared to ascertain locations once a title was identified, and many of the entries for which no location is given may be in Dutch or Belgian libraries. Scientific works and those relating strictly to interconfessional controversy were omitted.

The basis of the work was laid by W. Perquin in 1944 with several thousand slips. Between 1946 and 1950 Rev. L. Verschueren and ten collaborators expanded the file. In 1950 Rev. A. van Dijk of Louvain began to edit the whole body of material and prepare it for publication.

In spite of the history of the compilation, the finished work shows a high degree of accuracy. Comparison with such sources as the Nijhoff-Kronenberg Nederlandsche Bibliographie van 1500 tot 1540 shows that there are few errors. As a reference work the bibliography is essential to all students of general and religious history of Europe during the period of Reformation and Counter-Reformation.

In this sesquicentennial year of $H$ ans Christian Andersen's birth a flood of Ander- 
sen literature is appearing. Large numbers of Scandinavian gift books have been issued, and there is a very substantial volume of critical literature.

In the second volume of Fund og Forskning, the annual published by the Royal Library in Copenhagen, there are three Andersen articles. The most memorable, perhaps, is that of Erik Dal on the Royal Library's acquisition of the magnificent Andersen collection of Holger Laage-Petersen, with some 4,500 books, 400 letters by Andersen, and numerous other Andersen items. Many photographs of Andersen were taken by Henrik Tilemann, and some of them are in the Laage-Petersen collection. Bjørn Ochsner attempts to identify and date the Andersen photographs. A third Andersen article is by H. Topsøe-Jensen on the recent acquisition of the first half of the manuscript of "Little Ida's Flowers" by the Royal Library. The first half was in the Collin collection, long in the ownership of the Royal Library.

All but one of the essays in Volume II of Fund og Forskning are in Danish with detailed English summaries. The most interesting of all, however, is in English with a Danish résumé. It is the exciting story of the acquisition of a rare collection of Tibetan books for the Royal Library by Prince Peter of Greece and Denmark. Another fascinating story of the library's orientalia is in Leo Buschardt's essay on the Balinese correspondence of Mads Lange, nineteenth century Danish sailor and East India traveller. Tycho Brahe is the subject of two articles, one by Harald Mortensen on Brahe's library and another by Edv. Gotfredsen on the accounts of Brahe's last illness and death. Svend Dahl, retired director of the Royal Library, has made a valuable contribution to the history of library administration with his essay on Adam Wilhelm Hauch, appointed head librarian in I829. Mogens Haugsted has written on early Danish printers' and publishers' marks, Jean Anker on J. E. C. Walters' illustrated book on Scandinavian birds (I84I), Henning Einersen on the twenty-two incunabula acquired by the library since I 938 when Madsen's catalog listed some 4,300 pieces, R. Paulli on an eighteenth century silver filigree binding, the earliest Danish dedicated books, and the appreciation of Holberg's Nicolai Klimii Iter Subterraneum abroad. Few libraries can boast of equally stately collections as the Danish Royal Library, and few that can have such a handsome and useful publication as Fund og Forskning.

The second edition of Johann Schlemminger's Fachwörterbuch des Buchwesens; Deutsch-Englisch-Französisch (Darmstadt: Fachverlag Dr. N. Stoytscheff, I954; 367 pages; DM 14.80 ) is the best recent glossary of the book. It contains three alphabets, viz., (I) German-English-French, (2) EnglishGerman; and (3) French-German. It covers all aspects of book production, the book trade, and peripheral fields.

The new edition has superseded the earlier edition completely. It has some 6,000 technical words and phrases as against 3,500 in the first edition. Although there were relatively few errors in the French and English sections of the first edition, virtually all have been eliminated by unusually careful proofreading in the second edition. There are relatively few abbreviations, but they are clear and consistently used. An especially useful feature is the indication of the gender of the German words.

The Fachwörterbuch des Buchwesens has no exact counterpart among any of the three major languages of the world. There are specialized encyclopedias of bibliography and librarianship, there are glossaries of single fields of the book arts, and there are smaller glossaries of the book. However, none of these reference works combine in a single volume so many words and phrases relating to the book in English, French and German.

A major new biographical reference work is the Osterreichisches biographisches Lexikon, of which the first two fascicles, carrying the alphabet through Engelbert Dollfuss, appeared in 1954 in the Hermann Böhlau Verlag (Graz-Vienna-Cologne). Each fascicle is sold to subscribers for DM 6.50. There will be some five or six volumes, each consisting of about five fascicles. At present it is hoped to issue at least three fascicles a year.

Most of the sketches are fairly short, occupying at the most a single column (e.g., such prominent Austrians as Dollfuss or Edward von Bauernfeld). The sketches are unsigned but obviously have been subjected to rigid editorial standardization. Following each biography there is a list of the biographee's main works and a list of critical and biographical works about him. 
The origins of the Osterreichisches biographisches Lexikon go back to Anton Bettelheim, and Oswald Redlich, who planned a comprehensive biographical dictionary of all prominent Austrians from 1815 to 1918 . From 1923 to 1935 eight volumes of Ausgewählte Lebensbilder were published by the Amalthea Verlag, and a second series of shorter sketches was planned as a sort of a revision of Wurzbach. In 1946 the Österreichische Akademie der Wissenschaften established a "Kommission zur Ausarbeitung eines österreichischen biographischen Lexikons" under the chairmanship of Leo Santifaller, head of the Institute for Austrian Historical Research. Thus this work arose.

The scope includes all Austrians who resided on territory within the Austrian jurisdiction between 1815 and 1950 . All branches of activity are included. Thus the whole broad geographical area of the old Danube monarchy is included in this work. It is not difficult to uncover much of the motley color of old Austria in reading some of the sketches, despite the strictly scholarly methods of the editors.

The Österreichisches biographisches Lexi$k o n$ is a model work in every sense. It is conceived and executed according to the best standards of historical scholarship. Above all, however, it covers a part of the world that has not ceased to have a major significance in international affairs despite political splintering.

In every reference collection a basic history of each major country or major period has a place. The best example of such histories are perhaps the well known Cambridge histories. In Germany Johannes Bühler has brought out a major Deutsche Geschichte, now in its fifth volume (Berlin: W. de Gruyter, 1954; 518 pages; DM 32), covering the late eighteenth century and the nineteenth century through the Franco-Russian war.

Replete with selective bibliography and index in each volume, Bühler's work has a high value as a quick reference tool. On the other hand, Bühler is a fluent writer and a skillful interpreter of the historical past. His great work is good reading as well as a useful desk companion.

Bühler is particularly significant for treading the middle of the road path somewhere between the Nazi historians and the extreme revisionists who feel that the events of 1932-
1945 require a totally new interpretation of German history. Bühler is cautious, perhaps excessively so at times, but caution and modesty are the hallmarks of great historical writing. Bühler's work is perhaps more urgently needed because of German historical writing rather than because of German history. He brings to libraries and scholars the best comprehensive German history published in the last quarter of a century.

The second edition of Arthur Luther's Deutsches Land in deutscher Erzählung appeared in 1937, and the second edition of his Deutsche Geschichte in deutscher Erzählung appeared in 1943. Both bibliographies were unique reference works and enjoyed a useful life. When a third edition was considered, it was deemed most feasible to combine the two books into a single volume, Land und Leute in deutscher Erzählung (Stuttgart: Hiersemann, 1954; 555 pages; DM 28). The new edition had the dual purpose of including all pertinent material after 1937 and 1943 and of providing those who did not own the earlier works with a selection of their main content.

There has necessarily been a reduction in volume of the material in the earlier works, but the selection has been judicious. The entries for places under 20,000 inhabitants were omitted unless the localities in question had some special historical or cultural significance. From the Deutsche Geschichte it was decided to include only those titles which dealt with a definite personality in German history, and much fiction dealing only with historical events was dropped.

Nevertheless we have a stately number of titles. The first part of Land und Leute includes 430 places with about 8,000 titles of literary works using these places as a sett:ng. The second part lists 680 individuals with some 2,200 titles of biographical fiction and short stories. Memoirs, autobiography, juveniles, and cheap literature are omitted. There are indexes of places arranged geographically, of persons arranged chronologically, and of authors.

Land und Leute is a useful reference work for students on all levels of investigation. It has been found to be useful as a guide for undergraduate term papers as well as for graduate theses. Its reference value is obvious for any library with even a small collection of German literature. 
Existing reference books in the field of music are generally unsatisfactory in their treatment of music and musical instruments in antiquity and the early middle ages. Illustrations of instruments are isolated in out-ofthe-way serials and are not available for quick reference. This gap in reference material has been filled by Friedrich Behn with his Musikleben im Altertum und frühen Mittelalter (Stuttgart: Hiersemann, 1954; I 80 pages, Ioo plates; DM 35).

Behn surveys the history of music and musical instruments in twelve chapters of text followed by 100 plates containing $2 \mathrm{I} 7$ illustrations. The illustrations consist of photographs and drawings of the instruments, photographs of models, ancient mural paintings, statues of musicians, and reproductions of illuminated manuscripts. Every necessary detail of the instruments is shown.

While the illustrations lend a special value to Behn's work, the text is also valuable. Based on Behn's extensive research in archaeology and pre-history, the eleven chapters of the text cover not only Greece and Rome but also the ancient Near East, the nonRoman Italic peoples, the ancient Germanic and Celtic peoples, and the early middle ages up to the Carolingian period.

Behn's work will be useful not only for general music reference, but also as a tool for ancient historians, archaeologists, ethnologists, art historians, and literary historians. The research on which Behn has based his work is meticulous and dependable, and the book will be accepted by scholars in many fields.

In our day it is possible to single out a few librarians whose influence has been broad and enduring in every sense. Scholars as well as administrators, practical men as well as visionaries, such personalities as William Warner Bishop, Herbert Putnam, Wilhelm Munthe, Svend Dahl, Arundel Esdaile, and Georg Leyh have given the real substance to librarianship in our era. Mr. Bishop has given us fragments of autobiography, and the same thing would be more than welcome from his surviving contemporaries. George Leyh has given us a stately volume of fifteen essays selected by him as representative of nearly a quarter of a century of leadership in the library world. It is entitled Aus vierzig Jahren Bibliotheksarbeit; kleine Schriften (Wiesbaden; Otto Harrassowitz, I954; 26I pages; "Beiträge zum Buch- und Bibliothekswesen," III).

It is hardly possible to do full justice to each one of the essays in this volume, and only a few may be singled out for special mention. "Das Dogma von der systematischen Aufstellung," a truly noteworthy essay in the Zentralblatt für Bibliothekswesen for 1912 is the first in this volume. Classified shelving has been more of a religion than a dogma with us, but the time has now come when a few American librarians are reconsidering this religion. Leyh's essay must be essential reading for them. Essays on Fritz Milkau, F. A. Ebert, and Richard Pietschmann commemorate three of the truly great German librarians and extract broadly valid principles from their careers. Studies on the history of the University of Göttingen $\mathrm{Li}$ brary, on older administrative practices, and basic points of library history yield a historical perspective that may be valuable to all of us. An essay on professional ("wissenschaftlich") librarians and the middle service and their respective duties show keen insight into personnel problems.

After the catastrophe of World War II and retirement, Leyh was more active than ever. He not only undertook the tremendous jobs of surveying war damage to German libraries and editing the new edition of the Handbuch, but he also continued his research in other fields, his library historical studies (e.g., on Göttingen), and his theoretical speculative essays (e.g., "Der Bibliothekar der $\mathrm{Zu}$ kunft") in the Zentralblatt. The last essay, which appears here for the first time, is on "Der junge Jacob Burckhardt." It presents the results of a lifetime of study of the great art historian and the fruits of an astonishing activity as a collector. No other private collector has a Burckhardt collection that can approach Leyh's.

These fifteen essays permit us to come close to the heart of Leyh's thinking. It is a system of thought which has had a profound influence on the library world on both sides of the ocean.

Joris Vorstius, editor of the Zentralblatt für Bibliothekswesen, is the honoree of the Festschrift Joris Vorstius zum 60. Geburtstag: Bibliothek, Bibliothekar, Bibliothekswissenschaft (Leipzig: Harrassowitz, 1954; 440 pages; DM 24). In addition to a list of Vorstius' publications from 1917 to 
1953, there are thirty-one essays divided into three major sections, ( 1 ) bibliography and the theory of knowledge, (2) library administration and techniques and (3) the history of books and libraries. The most prominent librarians in all the Germanies have joined in giving homage to Vorstius, and the contributors include such well known names as Georg Leyh, Donker Duyvis, and Ilse Schunke.

It would be difficult to do full justice to all the important essays that have been printed in this volume. The fact that the book was edited in East Germany for an East German has brought such essays as one by Todor Borov, director of the Bulgarian Bibliographical Institute, on the primary national bibliography of Bulgaria, František Horák, director of the Ceskoslovenska Akademie Věd. Základni Knihovna in Prague, on the library of the Czech Academy of Sciences, and Othmar Feyl, librarian of the University of Jena, on the classification scheme for the bibliographies of the book chambers of the U.S.S.R. Leyh's little essay entitled "Bibliographisches" is another useful contribution to library history. Fritz Redenbacher's study of the building problems of the University of Erlangen Library is instructive for any librarian who wrestles with spatial issues. Ilse Schunke's notes on library history in Dresden are based on her study of bindings. Willi Gober, director of the old University of Berlin Library (to be distinguished from the new Free University Library), reviews the old problems of centralization versus decentralization, showing a strong tendency to the former in the present day. Hugo Alker reviews the history of subject cataloging in the University of $\mathrm{Vi}$ enna Library for the past two centuries. Donker Duyvis writes on the international significance of the Index Bibliographicus.

\section{FOLKWAYS RECORIDS}

World's leading producer of AUTHENTTC folk music on RECORDS, including THE ETHNIC FOIKWAYS LIBRARY which contains an unusual selection of the music of over 200 peoples, recorded on location by native orchestras and vocal groups; each Long Play Record is accompanied by extensive notes by famous collectors and recognized authorities

And the famous SONGS TO GROW oN series for chtldren ANTHOLOGY OF JAZZ and AMEIRICAN FOLK MUSI
series.

Most of the issues are original recordings on HIGH FIDELITY - 40-18,000 cycles. ALL FOLKWAYS RTCORDS are guaranteed for quality of reproduction and content.

For complete catalog write to:

FOLKWAYS RECORDS \& SERVICE CORP. 117 West 46th St., New York 36, N. Y.
These are but a few samples of a rich and instructive volume, well worthy of a librarian such as Vorstius, who himself has contributed so much to library literature. Unlike some homage volumes, this one is intelligently planned and executed, and its value is enhanced by an index of names and places. In every sense the Vorstius Festschrift is a significant contribution to librarianship.-Lawrence S. Thompson, University of Kentucky Library.

\section{Economical Cataloging:} A Reply

In the article "How Little Cataloging Can Be Effective" (c\&RL, April, I954), Mr. Wyllis Wright states that author dates shall not be recorded except to distinguish between authors of the same name represented in the catalog. It seems to me that it adds to the understanding of a book to know at what period of an author's lifetime a particular book was written. Only author dates in relation to the date of publication can tell whether a book was an early work, or written at the prime of the author's life, or shortly before his death.

A further simplification suggested by $\mathrm{Mr}$. Wright is to omit all translator notes, except on cards for those standard authors where a variety of translations may be expected. I feel as long as we trace and give credit to editors, joint editors, compilers, etc., we should trace for translators, too. In my opinion, translators make a greater contribution to a book than editors. To translate requires not only a strict conformity to the original text, it means also to recreate the original movement of thought, and in case of the translation of poetry, to recast the rhythm and rhyme inherent in the original line of the poem.

As to the omission of editor notes, one may be of the opinion that one person's use of the editor information (e.g. a candidate for a $\mathrm{Ph} . \mathrm{D}$. degree using this item) may make up for its lack of use by other students.

It seems to be very difficult to establish a criterion of usefulness of the cataloged information, because the use of the items on the catalog card is a value difficult to estimate in terms of figures and percentages. $-L u c y$ Selig, Cataloger, Dayton (O.) Public Library. 